University of South Carolina

Scholar Commons

1991

\title{
In Situ Degradation of Polyhalogenated Aromatic Hydrocarbons by Electrochemically Generated Superoxide Ions
}

\author{
E. E. Kalu \\ Texas A \& M University - College Station \\ Ralph E. White \\ University of South Carolina - Columbia, white@cec.sc.edu
}

Follow this and additional works at: https://scholarcommons.sc.edu/eche_facpub

Part of the Chemical Engineering Commons

\section{Publication Info}

Journal of the Electrochemical Society, 1991, pages 3656-3660.

(C) The Electrochemical Society, Inc. 1991. All rights reserved. Except as provided under U.S. copyright law, this work may not be reproduced, resold, distributed, or modified without the express permission of The Electrochemical Society (ECS). The archival version of this work was published in the Journal of the Electrochemical Society.

http://www.electrochem.org/

DOI: $10.1149 / 1.2085475$

http://dx.doi.org/10.1149/1.2085475

This Article is brought to you by the Chemical Engineering, Department of at Scholar Commons. It has been accepted for inclusion in Faculty Publications by an authorized administrator of Scholar Commons. For more information, please contact digres@mailbox.sc.edu. 
10. W. M. Vogel, L. J. Bregoli, and S. W. Smith, This Journal, 127, 833 (1980).

11. P. G. P. Ang and A. F. Sammells, ibid., 1287.

12. A. J. Appleby and S. B. Nicholson, J. Electroanal. Chem., 83, 309 (1977).

13. A. J. Appleby and S. B. Nicholson, This Journal, 127, $759(1980)$.

14. A. J. Appleby and S. B. Nicholson, J. Electroanal.
Chem., 112, 71 (1980).

15. J. R. Selman and H. C. Maru, in "Advances in Molten Salt Chemistry," Vol. 4, G. Mamantov and J. Braunstein, Editors, 159 (1981).

16. P. L. Spedding, This Journal, 120, 1049 (1973)

17. S. Tanase, Y. Miyazaki, M. Yanagida, K. Tanimoto, and T. Kodama, in "Progress in Batteries and Solar Cells," Vol. 6, p. 195 (1987).

\title{
In Situ Degradation of Polyhalogenated Aromatic Hydrocarbons by Electrochemically Generated Superoxide Ions
}

\author{
E. E. Kalu* and R. E. White ${ }^{\star \star}$ \\ Center for Electrochemical Engineering, Department of Chemical Engineering, Texas A\&M University, \\ College Station, Texas 77843
}

\begin{abstract}
The reduction of dioxygen in aprotic media yields superoxide ions which react with polyhalogenated aromatic hydrocarbons by nucleophilic substitution. The degradation of hexachlorobenzene to bicarbonates and chlorides using in situ generated superoxide ions was carried out at room temperature in a flow cell system equipped with a gas fed, porous electrode. The effects of current, electrolyte flow, and aprotic media on the extent of degradation of hexachlorobenzene are presented.
\end{abstract}

Polyhalogenated aromatic hydrocarbons include materials such as polychlorinated biphenyls (PCBs) and hexachlorobenzene. PCBs were first introduced by the Monsanto Company in 1929 and have been used extensively as both transformer oils and heat exchanger fluids because of their thermal, biological and chemical stability, and their high dielectric constant. These materials, which are classified as hazardous, represent a major environmental problem, with over 100 million pounds existing in mobile environmental reservoirs, landfills, and dumps (1). Thermal incineration, in either a high efficiency incinerator or a cement kiln, is the only legal method for disposal of liquid PCBs. The major disadvantage of this method is the emission of dioxins. The PEG process (2) is a chemical treatment method which can be used to remove PCBs but it is not as effective a process as needed. Biological degradation is very slow and costly (3). The direct electrochemical reduction of polyhalogenated (4) aromatics occurs in stepwise mode and also produces undesired intermediates such as the mono-, di-, and tri-chlorinated forms of the parent ring. Recently, it was discovered that superoxide ions can degrade polyhaloaromatics such as hexachlorobenzene and PCBs to bicarbonates and chlorides (5). These superoxide ions can be generated by the cathodic reduction of dioxygen in aprotic solvents such as dimethylformamide (DMF), dimethylsulfoxide (DMSO), acetonitrile $(\mathrm{MeCN})$, and pyridine, with dissolved ammonium salts serving as the electrolyte. The successful application of this method would be desirable for the removal of PCBs from contaminated fluids, such as the heat exchanger fluids used in electric transformers. The treatment method envisaged for such contaminated fluids would involve superoxide ion treatment followed by the separation, by evaporation, of the aprotic solvent (used for the generation of superoxide ions) for the final recovery of the treated fluid. For such fluids, the concentration of PCBs can be lowered to an acceptable level in ppm. The electrochemical superoxide ion method is also attractive because the technology is capable of being moved to, or located at, a site where $\mathrm{PCB}$ wastes or other similar wastes are being stored. This would eliminate the fear of residents near a proposed detoxification facility. Although superoxide salts such as potassium and sodium superoxide can serve as sources of superoxide ions, their limited solubility in organic solvents makes them of limited use for PCB degra-

* Electrochemical Society Student Member

*:* Electrochemical Society Active Member. dation. Electrolytic production of superoxide ions offers a convenient method to control the amount of $\mathrm{O}_{2}^{-}$and to generate continuously pure $\mathrm{O}_{2}^{-}$. The degradation of PCBs and hexachlorobenzene reported in (5) were carried out in laboratory test tubes. The objective of this work was to investigate the feasibility of destroying hexachlorobenzene in a flow cell using electrochemically generated superoxide ions. This paper describes the experimental methods used and the results of preliminary experiments conducted using DMSO and DMF as solvents and hexachlorobenzene as halogenated substrate.

\section{The Superoxide Ion Reaction Chemistry with Polyhaloorganics}

Superoxide ion is an anionic radical which can react either as an electron reducing agent, an electron donor, a base, an oxidant, or as a nucleophile (7). The reactions of superoxide ions with polychloroaromatic hydrocarbons are nucleophilic. Sugimoto et al. (6) have suggested a possible mechanism for the nucleophilic reaction of $\mathrm{O}_{2}^{-}$with hexachlorobenzene

$$
\begin{gathered}
\mathrm{C}_{6} \mathrm{Cl}_{6}+\mathrm{O}_{2}^{--} \rightarrow\left[\mathrm{C}_{6} \mathrm{Cl}_{6} \mathrm{O}_{2}^{-}\right] \rightarrow \mathrm{C}_{6} \mathrm{Cl}_{5} \mathrm{O}_{2}^{-}+\mathrm{Cl}^{-} \\
\mathrm{C}_{6} \mathrm{Cl}_{5} \mathrm{O}_{2}^{-}+\mathrm{O}_{2}^{--} \rightarrow \mathrm{C}_{6} \mathrm{Cl}_{4} \mathrm{O}_{2}+\mathrm{O}_{2}+\mathrm{Cl}^{-} \\
\mathrm{C}_{6} \mathrm{Cl}_{4} \mathrm{O}_{2}+10 \mathrm{O}_{2}^{--} \rightarrow 3 \mathrm{C}_{2} \mathrm{O}_{6}^{2-}+2 \mathrm{O}_{2}+4 \mathrm{Cl}^{-} \\
3 \mathrm{C}_{2} \mathrm{O}_{6}^{2-}+3 \mathrm{O}_{2}+3 \mathrm{H}_{2} \mathrm{O} \rightarrow 6 \mathrm{HCO}_{3}^{-}+3 / 2 \mathrm{O}_{2}
\end{gathered}
$$

According to the mechanism shown in Eq. [1] [4]; the initial step in Eq. [1] is the nucleophilic addition of superoxide ion to the hexachlorobenzene. A subsequent loss of chloride yields a benzoperoxy radical which is reduced by a second $\mathrm{O}_{2}^{-}$to become a peroxo nucleophile. This nucleophile attacks the adjacent carbochloro center with the displacement of chloride and formation of orthoquinone [2]. The orthoquinone formed undergoes facile reactions with superoxide ions to yield peroxy di-carbonate $\left(\mathrm{C}_{2} \mathrm{O}_{6}^{2-}\right)$ and chloride ions [3]. The $\mathrm{C}_{2} \mathrm{O}_{6}^{2-}$ ions are hydrolyzed by water to $\mathrm{HCO}_{3}^{-}$and $\mathrm{O}_{2}$ [4]. Thus the hexachlorobenzene is completely degraded by superoxide ions. Similar reactions were observed with PCB substrates. The reaction between superoxide ions and polychloroaromatics was postulated as a second order (6) homogeneous reaction, dependent on the concentrations of the substrate, hexachlorobenzene, and superoxide ions. In the presence of a high concentration of the halogenated substrate, an apparent pseudo first order reaction takes place. The rate constants for the 


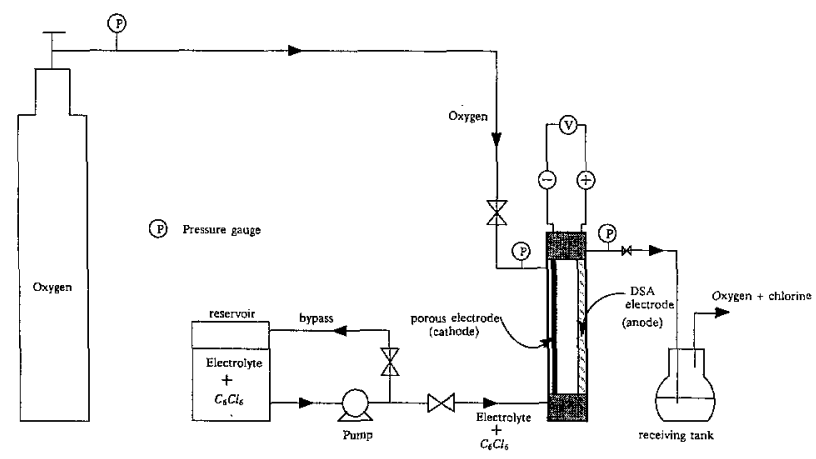

Fig. 1. Flow circuit diagram for in situ superoxide ion degradation of $\mathrm{C}_{6} \mathrm{Cl}_{6}$.

pseudo first order reactions determined for hexachlorobenzene in DMSO, MeCN, DMF, and pyridine (6) at $25^{\circ} \mathrm{C}$ were $47.0,92.0,1000$, and $47.0 \mathrm{M}^{-1} \mathrm{~s}^{-1}$, respectively. Thus the reaction is extremely fast in DMF at $25^{\circ} \mathrm{C}$ as compared to the other media.

\section{Experimental}

The effects of current, electrolyte flow, and solvent on the extent of degradation of hexachlorobenzene were studied. The reactions were carried out in a once through flow circuit as shown in Fig. 1. The reactor used was a bench scale multipurpose continuous flow electrochemical reactor manufactured by ElectroCell Co., Akersberga, Sweden. Both the active part of the anode and the cathode were $10 \mathrm{~cm}$ long by $10 \mathrm{~cm}$ wide. The cell housing pieces were all of polypropylene. The porous electrode used as the cathode was a graphite gas diffusion electrode, Prototech, MA, loaded with platinum particles $0.3 \mathrm{mg} / \mathrm{cm}^{2}$ but without Teflon backing. The thickness of the cathode was $0.36 \mathrm{~mm}$. The anode material was a $0.3 \mathrm{~cm}$ thick chlorine DSA electrode, supplied by Electrosynthesis, Inc., NY. Neoprene gaskets, $0.3 \mathrm{~cm}$ thick, i.e., effective liquid layer thickness of $0.3 \mathrm{~cm}$, were used while a polypropylene flow frame provided an effective interelectrode gap of about $7 \mathrm{~mm}$. The flow electrolysis experiments were carried out in the constant current mode. The potential across the cell and the applied current were measured by the use of a multimeter, John Fluke Co., Seattle. Burdick and Jackson "distilled in glass" UV-grade DMSO and DMF were used as received for all of the experiments. Tetraethylammonium perchlorate (TEAP) from the G. Frederick Smith Chemical Co. was used as the supporting electrolyte, $0.2 M$ TEAP, without further purification. Hexachlorobenzene $\left(\mathrm{C}_{6} \mathrm{Cl}_{6}\right)$, from the Aldrich Chemical Co., given as $99.0 \% \mathrm{pu}-$ rity was used without further purification for most of the experimental runs, with the exception of a few where the samples were recrystallized before use for comparative purposes. Oxygen was $>99.0 \%$. In the operation of the cell, between 1.5 and $3.0 \mathrm{mM}$ solution of hexachlorobenzene, oxygen sparged, was introduced through the bottom of the reactor to flow upwards past the front of the cathode. Oxygen was introduced into the system through the back side of the porous electrode. The arrangement was such that the oxygen moved or diffused into the solution in such a manner that little or no bubbles were made in the flowing liquid, gas diffusion through the electrode into the flowing stream. The oxygen flow was kept constant for all the runs at $10.0 \mathrm{~cm}^{3} / \mathrm{s}\left(25^{\circ} \mathrm{C}\right)$ at an upstream gauge pressure of 10 $\mathrm{kpa}$. The system was not optimized for oxygen pressure. The independent variables examined for the reactor performance were the current, 100-600 mA; electrolyte flow, $1.0-10 \mathrm{~cm}^{3} / \mathrm{min}$; and the solvent, DMF, DMSO. The concentrations of starting material and products of the reaction were related to (used a biphenyl internal standard) the response of a gas chromatography, Hewlett-Packard 5890, equipped with a Ni electron capture detector. The capillary column used was a Hewlett-Packard fused silica capillary column, loaded with cross-linked methyl silicone. The capillary column ID was $0.20 \mathrm{~mm}$ and had a total length of $12.5 \mathrm{~m}$. A mixture of $5 \%$ methane and $95 \%$ argon was used as the carrier gas, and the flow rate was $46 \mathrm{~cm}^{3}$ \%

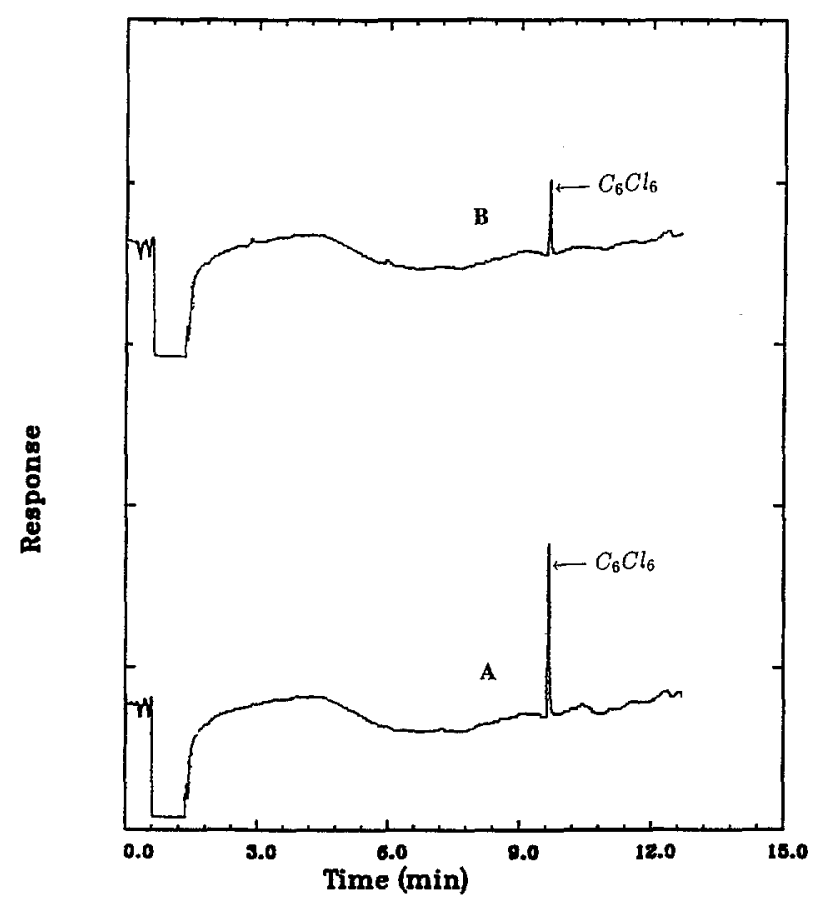

Fig. 2. Typical GC analysis output results in $D M F$, unpurified $C_{6} C l_{6}$. A: $\mathrm{C}_{6} \mathrm{Cl}_{6} \mathrm{GC}$ signal before being passed through the reactor. $\mathrm{B}: \mathrm{C}_{6} \mathrm{Cl}_{6}$ $\mathrm{GC}$ signal after one pass through electrochemical reactor. Conditions: current $=3.0 \mathrm{~mA} / \mathrm{cm}^{2}$, flow $=4.0 \mathrm{~cm}^{3} / \mathrm{min}$ Area under GC peak: $A=$ 20,345 units, $B=8,813$ units, $\%$ extent of degradation $=[1.0-$ $8,813 / 20,345] \cdot 100=57.8 \%$.

min at an inlet pressure of $400 \mathrm{kpa}$. The column was held at $190^{\circ} \mathrm{C}$ for $2.0 \mathrm{~min}$ and then subjected to temperature programming at a ramp rate of $20^{\circ} \mathrm{C} / \mathrm{min}$ for $3.0 \mathrm{~min}$ to a final temperature of $250^{\circ} \mathrm{C}$ and was left here for a final time of 2.0 min. A fresh solution of $\mathrm{C}_{6} \mathrm{Cl}_{6}$ in DMSO or DMF of known concentration, prepared in our laboratory, was used as a standard for each day of analysis. A typical GC output signal from the unreacted feed and product streams are shown in Fig. 2. To obtain the extent of degradation, the area under the GC response peak for the treated sample was divided by that of the feed sample and the value obtained subtracted from 1.0 For instance in Fig. 2, the operating conditions were: current $=3.0$ $\mathrm{mA} / \mathrm{cm}^{2}$, flow rate $=4.0 \mathrm{~cm}^{3} / \mathrm{min}, \mathrm{DMF}$, and unpurified $\mathrm{C}_{6} \mathrm{Cl}_{6}$ sample. The area under peak $\mathrm{A}$, fresh feed, $=20,345$ units and $B$, treated sample, $=8,813$ units. A calculation of the extent of degradation for the sample yielded $57.8 \%$. We tested for the lower chlorinated products of the ring including pentachlorophenol by the comparison of the product stream GC signals against the signals from known concentration of the aforementioned species. The changes observed in the comparison of $\mathrm{C}_{6} \mathrm{Cl}_{6} \mathrm{GC}$ signal between the feed stream and product stream was interpreted as due to superoxide ions reaction with hexachlorobenzene. The presence of chloride in the product mixture was tested for by the potentiometric titration of this mixture with $\mathrm{AgNO}_{3}$.

\section{Results and Discussion}

The extent of the degradation of hexachlorobenzene was determined by comparing the GC signal of the product stream to that of the feed stream. Preliminary experiments showed that the GC signal for $\mathrm{C}_{6} \mathrm{Cl}_{6}$ decreased with an increase in the current at any given electrolyte flow. During these preliminary experiments, it was discovered that the porous electrode could not be effectively operated in the typical gas diffusion mode. Thus, the gas from the back side was allowed to pass, sparged, through into the solution thereby giving rise to only a single exit out of the reactor. We thus report here the results obtained using this mode of operation of a porous gas diffusion electrode. At different superficial current densities and a constant electrolyte flow of a particular solvent, there was an increase in 


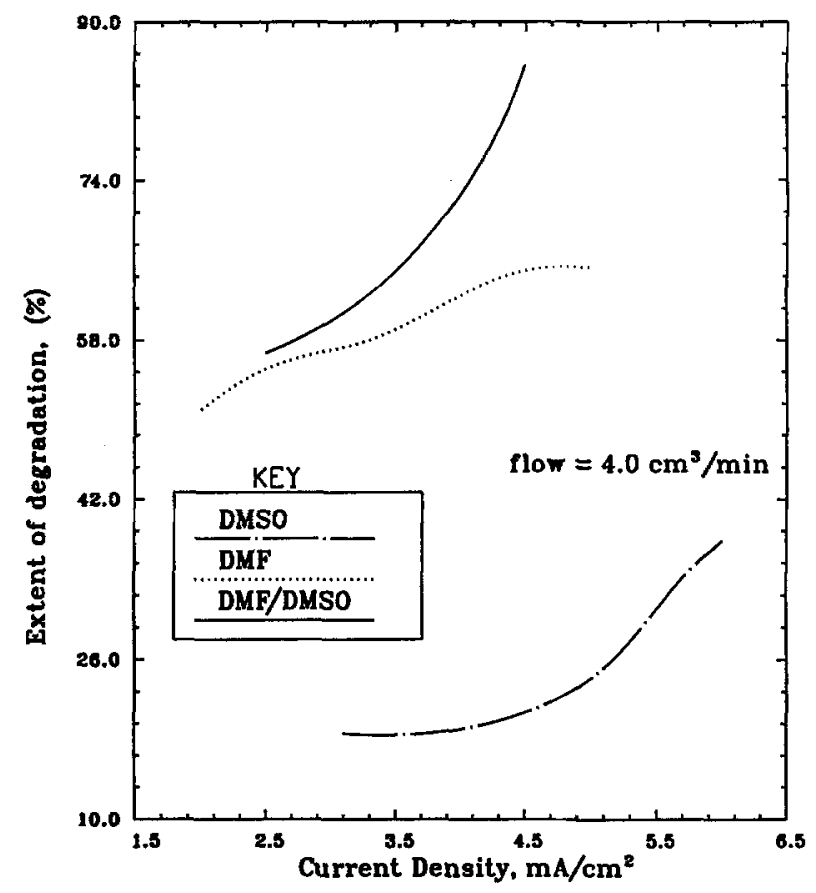

Fig. 3. Extent of $\mathrm{C}_{6} \mathrm{Cl}_{6}$ (unpurified) degradation in DMSO, DMF, and DMF/DMSO mixture against applied current at a constant electrolyte flow of $4.0 \mathrm{~cm}^{3 /} / \mathrm{min}$.

the extent of degradation of $\mathrm{C}_{6} \mathrm{Cl}_{6}$ with an increase in the current density, Fig. 3 , and this was observed when the solvent was DMSO, DMF, and DMSO/DMF, $50 \%$ by volume, mixture. The current density was calculated based on electrode area calculated from its geometrical length and width. A possible explanation for the observed behavior could be that with the increase in current more superoxide ions were generated. An increased amount or concentration of superoxide ions in the electrolyte will result in more $\mathrm{C}_{6} \mathrm{Cl}_{6}$ being reacted or degraded. Furthermore, the figure shows that the overall cell performance, measured by percentage degradation of $\mathrm{C}_{6} \mathrm{Cl}_{5}$, in the solvent systems are in the descending order DMF/DMSO $>\mathrm{DMF}$ $>$ DMSO. The results of Fig. 3 were obtained with $\mathrm{C}_{6} \mathrm{Cl}_{6}$ that was not recrystallized, i.e., $\mathrm{C}_{6} \mathrm{Cl}_{6}$ was used as received. The differences in performance for the solvent systems could be due to the combined effects of the differences in the conductivity of the solvents and the physical properties of oxygen in the media. If the physical properties of oxygen in these media were responsible for the observed performance differences alone, one could only use it to explain the differences between the results obtained in DMF and DMSO. This is because in DMF, the solubility and diffusion coefficient of oxygen, $25^{\circ} \mathrm{C}$ and $1 \mathrm{~atm}$, are given as $4.8 \mathrm{mM}$ and $6.3 \times 10^{-6} \mathrm{~cm}^{2} / \mathrm{s}$, respectively, as against a solubility and diffusion coefficient value of $2.1 \mathrm{mM}$ and $3.6 \times$ $10^{-6} \mathrm{~cm}^{2} / \mathrm{s}$, respectively, in DMSO (8). However, since the extent of degradation is greater for the DMF/DMSO mixture, it is likely the solubility and diffusion coefficient of oxygen cannot explain the results, and other physical properties such as dielectric constant and conductivity must be considered. When a sample of $\mathrm{C}_{6} \mathrm{Cl}_{6}$ was used as received in DMSO at a current density of $3.0 \mathrm{~mA} / \mathrm{cm}^{2}$ and electrolyte flow of $4.0 \mathrm{~cm}^{3} / \mathrm{min}$, the GC signal for the product stream decreased by only $18.6 \%$. This value contrasted with the decrease of $77.0 \%$ obtained with a recrystallized sample of $\mathrm{C}_{6} \mathrm{Cl}_{6}$ under the same operating conditions. Based on this observation, the operating current density was doubled to $6.0 \mathrm{~mA} / \mathrm{cm}^{2}$ and used for the dehalogenation of an unpurified sample. Except for the current density and purity of $\mathrm{C}_{6} \mathrm{Cl}_{6}$ differences, all other operating conditions were the same for the two runs. The results obtained in these two runs are shown in Fig. 4. The interesting observation here is the lower degradation performance achieved by the higher current density. The figure suggests that the $\mathrm{C}_{6} \mathrm{Cl}_{6}$ sample that was used as received might

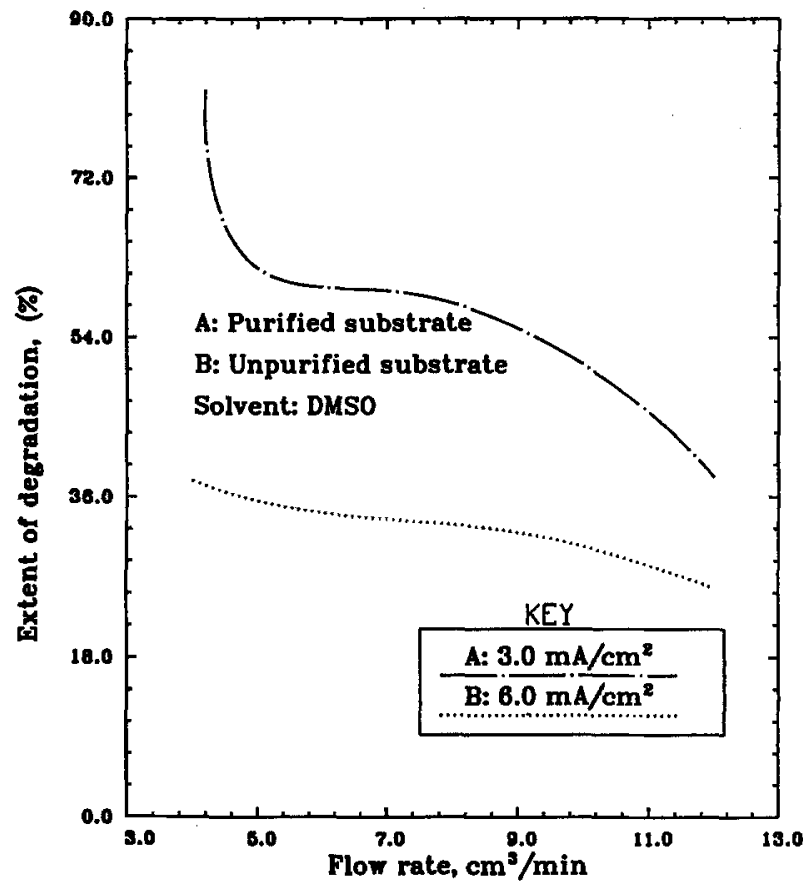

Fig. 4. Effect of $\mathrm{C}_{6} \mathrm{Cl}_{6}$ purification on the degradation efficiency in DMSO solvent.

have contained contaminants that were detrimental to the generation of superoxide ions or competed with $\mathrm{C}_{6} \mathrm{Cl}_{6}$ for superoxide ions. The possibility of a ferric chloride contaminant, commonly found in $\mathrm{C}_{6} \mathrm{Cl}_{6}$, being a factor here was discounted since the applied cell voltage and operating current density were considered too low to be used for a possible decomposition of the salt. The comparative study between the purified and unpurified samples. was limited to DMSO solvent. The remaining studies were conducted with unpurified $\mathrm{C}_{6} \mathrm{Cl}_{6}$ samples. A plot of electrolyte flow against the extent of $\mathrm{C}_{6} \mathrm{Cl}_{6}$ degradation at a constant current density of $3.0 \mathrm{~mA} / \mathrm{cm}^{2}$ is shown in Fig. 5 for the solvent systems reported here. The figure shows that the relative degradation was highest in a DMF/DMSO solvent system at any given condition studied. The pattern here for the solvents follows the same pattern observed in Fig. 3.

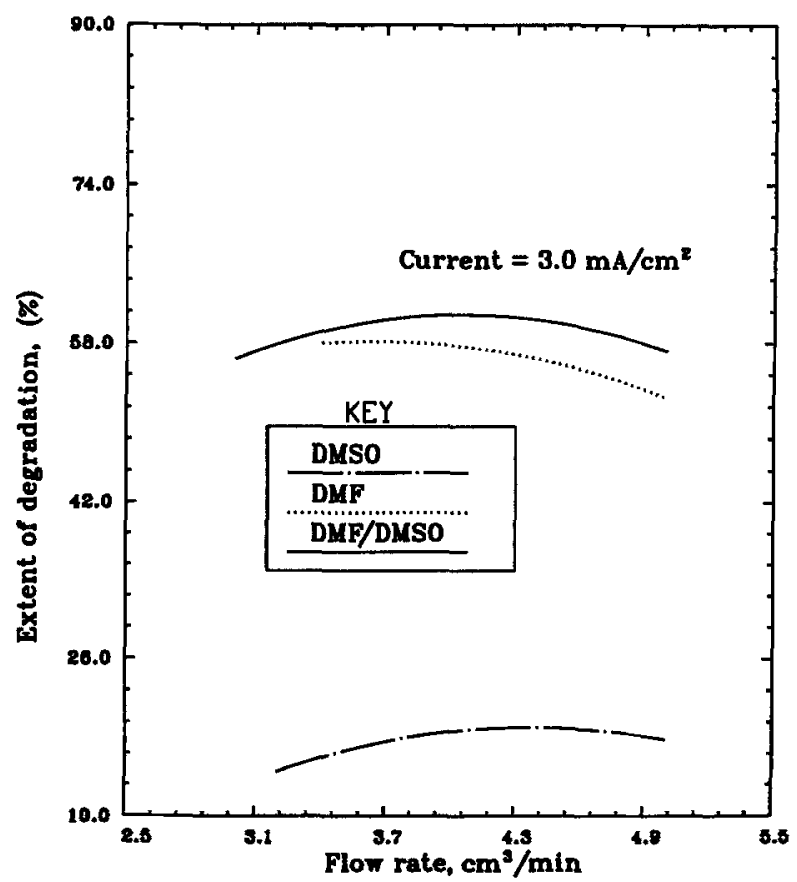

Fig. 5. Effect of Hlow rate on the extent of $\mathrm{C}_{6} \mathrm{Cl}_{6}$, unpurified, degradation at a superficial current density of $3.0 \mathrm{~mA} / \mathrm{cm}^{2}$. 
However, the relationship between flow rate and extent of degradation is not well defined. For instance, in DMSO, it seemed that within the range of study, the degradation increased with flow for flows below $4.0 \mathrm{~cm}^{3} / \mathrm{min}$. Above 4.0 $\mathrm{cm}^{3} / \mathrm{min}$, the extent of degradation seemed to decrease with increase in flow. Similar trend as observed in respect to DMSO occurred when the solvent was a DMF/DMSO mixture. In the case of DMF, the range of flow studied did not provide enough evidence for such an inference to be made. The reproducibility of the results in this work including those reported in Fig. 5 was about $\pm 10 \%$. Figure 5 suggests then, that for DMSO, DMF, and DMF/DMSO solvent systems, flow rate is a critical factor in determining the extent $\mathrm{C}_{6} \mathrm{Cl}_{6}$ could be degraded. More experimental data are needed to be able to prescribe an optimal flow for each of the solvent systems. It was not pursued in this work.

Current efficiency.-Based on Eq. [1]-[4], the overall equation for the degradation of $1 \mathrm{~mol}$ of $\mathrm{C}_{6} \mathrm{Cl}_{6}$ requires 12 mol of superoxide ions which is equivalent to about 12 Faradays of electricity. Thus the current efficiency for superoxide ion generation for the system can be expressed in the form

$$
\eta_{\mathrm{O}_{\overline{2}}}=\frac{1200 \mathrm{FQ}\left(\mathrm{C}_{1}-C_{2}\right)}{I}
$$

where $C_{1}=$ feed stream concentration for $\mathrm{C}_{6} \mathrm{Cl}_{6}, \mathrm{~mol} / \mathrm{cm}^{3}$, $C_{2}=$ product stream or exit concentration for $\mathrm{C}_{6} \mathrm{Cl}_{6}, \mathrm{~mol} /$ $\mathrm{cm}^{3}$, and $Q=$ electrolyte flow rate, $\mathrm{cm}^{3} / \mathrm{s}$.

A typical result obtained using Eq. [5] is shown in Fig. 6 for the DMF/DMSO Fig. 6 solvent system. The result indicates that the current efficiency at a constant current density of $4.5 \mathrm{~mA} / \mathrm{cm}^{2}$ increased with electrolyte flow till a value of $6.0 \mathrm{~cm}^{3} / \mathrm{min}$ where the efficiency levels off. The current efficiency variation with flow contrasted with the degradation variation with flow. Unlike the current efficiency which was lower at low electrolyte flows, the degradation efficiency was higher at low flows. A more appropriate determination of the superoxide ion generation current efficiency could have involved a direct measure of the superoxide ion concentration in a non $\mathrm{C}_{6} \mathrm{Cl}_{6}$ containing solvent. Such a direct determination of the concentration of generated superoxide ion was beyond the scope of this work.

Cell voltages.--The cell voltage was observed to increase with the operating current density at a constant electrolyte flow for each of the solvents studied. Figure 7 shows that relative to DMF or DMF/DMSO, the cell voltage was lower in DMSO at any given current density. This is accounted for by the higher dielectric constant, related to conductiv-

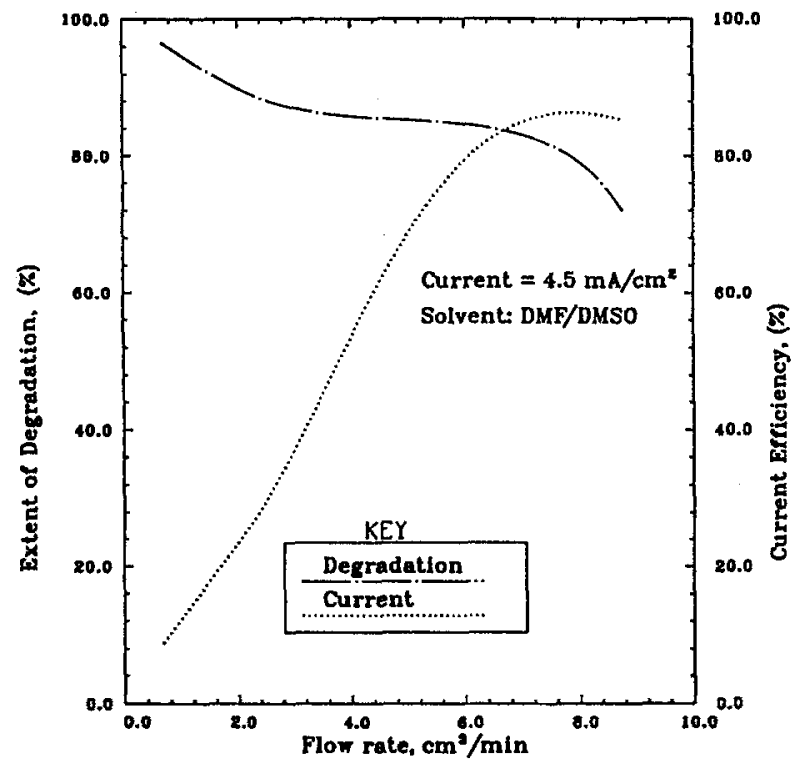

Fig. 6. Calculated superoxide ion current efficiency variation with flow for DMF/DMSO solvent mixture.

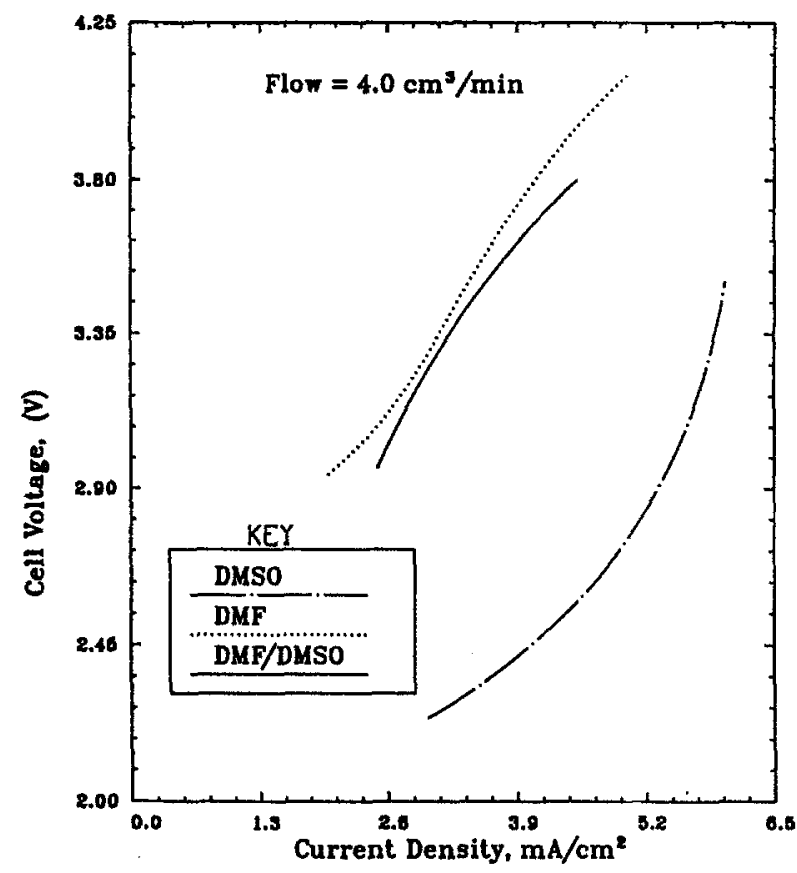

Fig. 7. Cell voltage variation in DMSO, DMF, and DMF/DMSO mixture with current at a constant flow of $4.0 \mathrm{~cm}^{3} / \mathrm{min}$.

ity, of DMSO. The figure further shows that the results obtained for DMF/DMSO mixture were closer to those of DMF. This is surprising since equal volumes of DMF and DMSO were used in the mixture. Under the same operating conditions, one would intuitively expect the cell voltage for the DMF/DMSO mixture solvent to be higher than that of DMSO but lower than the value for DMF. The present result in cell voltage, where the cell voltage for the DMF/DMSO mixture is closer to the value obtained in DMF solvent, was not expected. The result suggests, then, that in a mixture, solvents do not act alone but rather they act interactively, non-ideality, for the ionization of the supporting electrolyte.

\section{Conclusion}

The results obtained in this work show that the degradation efficiency reported in [5], almost $100 \%$, for a batch system was not duplicated for a once flow through reactor. The disagreement between the results of this work and the batch results of [5] indicates the complexity introduced into the system performance due to the flow effects. Theoretically, the closer the flow approaches zero, the more likely the $100 \%$ degradation efficiency will be approached. This was observed in DMF/DMSO solvent system, Fig. 6. This preliminary work shows that in situ generated superoxide ions in a once through flow reactor, equipped with a porous electrode, could be used for the partial degradation of hexachlorobenzene. The anode reactions, thought to be chlorine oxidation, see Ref. (5) and (6), apparently do not interfere with the homogeneous chemical reaction between the superoxide ions and the polychlorinated substrate. This is because no observation was made of chlorinated products other than $\mathrm{C}_{6} \mathrm{Cl}_{6}$. The flow rates or residence times of the electrolyte in the reactor and the applied current density affect the level of substrate destruction achievable. The type of solvent in use also influences the degradation efficiency. The experimental results demonstrate that under the same operating conditions, the percentage degradation achievable was highest in DMF/DMSO solvent, followed by DMF and, finally, DMSO. The purity of the substrate was also found to be a factor in the degradation efficiency.

\section{Acknowledgments}

We express our appreciation to Professor D. T. Sawyer and Dr. P. Tsang of the Chemistry Department at Texas A\&M University for their suggestions. This work was carried out with funding from the Captiva Capital Inc. 
Manuscript submitted on May 21, 1990; revised manuscript received on June 17, 1991.

Texas A\&M University assisted in meeting the publication costs of this article.

\section{LIST OF SYMBOLS}

$\mathrm{C}_{1}, \mathrm{C}_{2}$ exit and inlet concentration of $\mathrm{C}_{6} \mathrm{Cl}_{6}$ respectively, $\mathrm{mol} / \mathrm{cm}^{3}$

F Faraday's constant, $96,487 \mathrm{C} / \mathrm{mol}$

$I$ total current, A

$Q \quad$ volumetric flow rate of electrolyte, $\mathrm{cm}^{3} / \mathrm{s}$

$\eta_{\mathrm{O}_{2}} \quad$ current efficiency for superoxide ion generation

\section{REFERENCES}

1. J. Waid, "PCB's and the Environment," CRC Press, Boca Raton, FL, Vol. I-III, (1986).
2. J. D. Brunelle, A. K. Mandiratta, and A. D. Singleton, Environmental Science Tech., 19, 740 (1985).

3. P. N. Cheremisinoff, Pollution Engineering, 64 (1988).

4. S. O. Farwell, F. A. Beland, and R. D. Geer, Electroanal. Chem. Interfacial Electrochem., 61, 304 (1975); ibid., 61, 315 (1975).

5. H. Sugimoto, J. Masumoto, and D. T. Sawyer, Environ. Sci. Technol., 22, 1182 (1988).

6. H. Sugimoto, J. Masumoto, and D. T. Sawyer, J. Am. Chem. Soc., 109, 8081 (1987).

7. A. A. Frimer, in "The Chemistry of Functional Groups: Peroxides," S. Patai, Editor, pp. 429-461, Wiley, Chichester (1983).

8. D. T. Sawyer, G. Chiericator, Jr., C. T. Angelis, E. J. Nanni, Jr., and T. Tsuchiya, Anal. Chem., 54, 1720 (1982).

\title{
Attachment of $\mathrm{TiO}_{2}$ Powders to Hollow Glass Microbeads: Activity of the $\mathrm{TiO}_{2}$-Coated Beads in the Photoassisted Oxidation of Ethanol to Acetaldehyde
}

\author{
N. B. Jackson, ' C. M. Wang, Z. Luo, J. Schwitzgebel, J. G. Ekerdt, J. R. Brock, and A. Heller* \\ Department of Chemical Engineering, University of Texas, Austin, Texas 78712
}

\begin{abstract}
Methods for attaching $\mathrm{n}-\mathrm{TiO}_{2}$ particles to hollow microbeads of 80-100 $\mu \mathrm{m}$ average diam and $0.4-0.7 \mathrm{~g} \mathrm{~cm}^{-3}$ density are discussed. The floating photoactive microbeads were designed for use in solar-assisted oxidative dissolution of oil films on water. Photoactive beads caused the oxidation of ethanol molecules by dissolved dioxygen to acetaldehyde when exposed to $>3 \mathrm{eV}$ incident photons. Particularly photoactive beads were obtained by attaching Degussa $\mathrm{P}_{25} \mathrm{TiO}_{2}$ particles to aluminosilicate glass microbeads of $\sim 10 \mu \mathrm{m}$ wall thickness by physisorbing the $\mathrm{TiO}_{2}$ particles and bonding thermally at $300^{\circ} \mathrm{C}$. The $\mathrm{TiO}_{2}$ thermally bonded to aluminosilicate beads was stable in water and UV light, producing 0.7 mol of acetaldehyde per einstein. Acetaldehyde was produced at an efficiency of 0.5 mol/einstein in the photoassisted oxidation of ethanol on $\mathrm{TiO}_{2}$-activated borosilicate microbeads, which were made by a process where triethoxysilane was used as binder and ethanol was eliminated in the reaction with surface $\mathrm{OH}$ groups. One week of exposure to water caused the borosilicate glass microbeads to dissolve. The aluminosilicate glass was, however, not water-soluble, and the bound $\mathrm{TiO}_{2}$ particles did not detach from the bead.
\end{abstract}

With the objective of photoassisting the oxidative dissolution of oil spills, we have undertaken a study of attaching $\mathrm{n}-\mathrm{TiO}_{2}$ particles to hollow glass microbeads having sufficiently low densities to float on oil or water. Already, $\mathrm{n}-\mathrm{TiO}_{2}$ is well known to photoassist the oxidation of organic pollutants in water by dioxygen (1-14). The attachment of photocatalytic semiconductors to supports has been the subject of a series of studies (15-29). This paper discusses methods of attachment of $\mathrm{TiO}_{2}$ to sodium borosilicate and aluminosilicate glasses and the photoactivity of the resulting microbeads.

\section{Experimental}

The types of hollow microbeads used are listed in Table I. Two are sodium borosilicate glasses (PQ Corporation Q-Cel ${ }^{\circledast 3} 300$ and 600), and two are aluminosilicate glasses (PQ Corporation SG and SLG). The borosilicate beads were provided by the manufacturer with $5 \%$ amorphous silica dessicant that was removed by washing with water prior to use. Thermogravimetric analysis showed that, upon heating, the Q-Cel ${ }^{\circledR} 300$ beads lost $20 \%$ of their weight before reaching $400^{\circ} \mathrm{C}$. Since their infrared spectrum shows a large amount of water and no organic material, the thermal weight loss of the bead was attributed to a loss of water. The water desorbed in two temperature domains between 150 and $180^{\circ} \mathrm{C}$ and between 320 and $400^{\circ} \mathrm{C}$. The borosilicate beads dissolve slowly in water, disintegrating in about one week. They dissolve in both acidic and basic solutions and break while undergoing $30 \mathrm{~min}$

* Electrochemical Society Active Member.

1 Present address: Sandia National Laboratories, Albuquerque, New Mexico 87185. photoactivity tests in stirred aqueous solutions. The easy dissolution of the Q-Cel ${ }^{\circledast}$ beads results from the known hydrolytic attack of borosilicate glass surfaces by water that affects the chemical and mechanical properties of the glass $(30,31)$. The Q-Cel ${ }^{\circledast}$ beads have walls only $2-4 \mu \mathrm{m}$ thick, so any attack weakens the bead. The aluminosilicate beads of Table I, also purchased from PQ Corporation, were far more stable and also had a higher crush-strength than the $\mathrm{Q}-\mathrm{Cel}{ }^{\circledR}$ beads. These beads did not readily dissolve even in $6 M \mathrm{HCl}$ or in $6 \mathrm{M} \mathrm{NaOH}$, and did not appear to be attacked by water in a two-week exposure test.

The $\mathrm{n}-\mathrm{TiO}_{2}$ samples used were obtained from Degussa Corporation, Teterboro, NJ, and from Sachtleben Chemie GMBH, Duisburg-Homberg, Germany. The Degussa material, designated $\mathrm{P} 25$, had a surface area of $50 \mathrm{~m}^{2} \mathrm{~g}^{-1}$, a narrow particle size distribution, and an average particle size of $0.1 \mu \mathrm{m}$. The material was $75 \%$ anatase and $25 \%$ rutile. The Sachtleben material, designated Hombitan, had a surface area of $10 \mathrm{~m}^{2} \mathrm{~g}^{-1}$, a broader particle size distribution, and an average particle size of $0.2 \mu \mathrm{m}$. This material was $97 \%$ anatase.

Attachment of $\mathrm{TiO}_{2}$ - - The catalyst beads prepared by silane coupling attachment were pretreated by heating overnight in air at $100^{\circ} \mathrm{C}$. Five grams of triethoxysilane (TES) were refluxed with $5 \mathrm{~g}$ glass beads for $2 \mathrm{~h}$ in $200 \mathrm{ml}$ glacial acetic acid. Next, $1.2 \mathrm{~g} \mathrm{TiO}_{2}$ powder was added and then refluxed for $1 \mathrm{~h}$. After refluxing, the beads were washed first with tetrahydrofuran to remove the acetic acid, and then with water until the solution was clear. The beads were dried in air at $100^{\circ} \mathrm{C}$. In a modified version of this method used for attaching $\mathrm{TiO}_{2}$ to the aluminosilicate 